\title{
Research on the Situation of Mid- and Long-term Incentive Mechanism Construction in State-owned Power Enterprises
}

\author{
Wang Han $^{1, *}$ Tang Guangrui ${ }^{1}$ Liu Zuoming ${ }^{2}$ \\ ${ }^{1}$ State Grid Energy Research Institute Co.,Ltd., Beijing, 102209, China \\ ${ }^{2}$ State Grid Jilin Electric Power Co., Ltd. Electric Power Research Institute., Changchun, 130021, China \\ * Corresponding author's e-mail: wanghan@sgeri.sgcc.com.cn
}

\begin{abstract}
With the deepening of the reform of state-owned assets and state-owned enterprises and the reform of power supply tips, the construction and improvement of medium- and long-term incentive mechanisms for state-owned power enterprises are also facing a new situation. In this regard, state-owned power companies are required to actively respond to reform pressures and make full use of mid- and long-term incentives to effectively enhance employee vitality. On the other hand, it also laid a good foundation for the state-owned power enterprises to vigorously develop and promote mediumand long-term incentives. By summarizing and analyzing the forms currently faced by the medium- and long-term incentive mechanism construction of state-owned power enterprises, I provide reference and reference for related companies to carry out medium- and long-term incentive work.
\end{abstract}

Keywords: Mid- and Long-term Incentive, Power Enterprises, State-owned Enterprises

\section{INTRODUCTION}

In recent years, with the deepening of the reform of state-owned assets and state-owned enterprises and the reform of the power system, the State-owned Assets Supervision and Administration Commission has put forward higher requirements for the performance evaluation of state-owned enterprises. The challenges and pressure faced by state-owned enterprises are increasing day by day. How to effectively improve the incentive mechanism of key core talents such as management talents, scientific research talents and market-oriented business talents, further enhance the vitality of enterprises, mobilize entrepreneurs and the majority of employee officers to start businesses, stimulate the endogenous power of core backbone talents, and maintain the stability of the talent team Is the key to promoting the steady development of state-owned power enterprises.

With the continuous advancement of reforms related to state-owned enterprises, medium- and long-term incentive measures such as equity incentives, dividend incentives, and employee stock ownership take effect in a large number of state-owned enterprises.[1] As of May 2019, 92 listed companies controlled by 45 central enterprises have implemented equity incentive plans, 104 incentive schemes of 24 science and technology subenterprises affiliated to the central enterprise have entered the implementation stage, 181 enterprises have carried out pilot projects of employee shareholding in state-owned mixed ownership enterprises.

Although the current enterprises have carried out a lot of work in promoting the mid- and long-term incentive work for key core talents, and have made considerable progress, the construction of the mid- and long-term incentive system has also been given as an important task in the process of actively implementing the reform of the talent development system Listed. However, as the pace of reform continues to accelerate, and the three system reforms continue to deepen, the mid- and long-term incentives for state-owned power companies face increasingly complex environments and stricter requirements, and they need to be continuously improved and improved. 


\section{STATE-OWNED ENTERPRISES' MID- AND LONG-TERM INCENTIVE POLICIES ARE IMPROVING}

In recent years, with the acceleration of the reform of state-owned enterprises, the state has successively issued a series of policy documents on medium- and long-term incentives for state-owned enterprises. Encourage the promotion of various forms of medium- and long-term incentives for state-owned enterprises, increase the role and effectiveness of medium- and long-term incentives, and regulate the implementation of various types of medium- and long-term incentives for state-owned enterprises from top to bottom.

\subsection{Support and Encourage State-owned Enterprises in Mid- and Long-term Incentives in Top-level Design Documents}

The Party Central Committee and the State Council have repeatedly emphasized the necessity of mid- and long-term incentives and the use of mid- and long-term incentives in the top-level design documents on deepening the reform of mixed ownership of state-owned enterprises, advancing the "double hundred actions" of state-owned enterprise reforms, and innovation-driven high-quality development, Strengthen the exploration and implementation of mid- and long-term incentives.

For example, in the "Guidelines for the Operation of Central Enterprise Mixed Ownership Reform" promulgated in October 2019, the incentive and restraint mechanism is specifically explained.[2] It requires "encourage mixed ownership enterprises to comprehensively use medium- and long-term incentive policies such as employee shareholding of state-owned mixed ownership enterprises, equity incentives in stateowned listed companies, equity in state-owned technology companies, and dividend incentives, and explore excessive profit sharing, project follow-up, and virtual equity The medium- and long-term incentive method focuses on giving full play to the positive role of non-material incentives, and systematically enhances the comprehensive effect of positive incentives."

It is also like the "Circular of the State Council Reform and Leading Group of the State Council on Supporting and Encouraging" Double Hundred Enterprises "to Further Increase Reform and Innovation." It is clearly stated that " 'Double Hundred Enterprises' can comprehensively use medium- and long-term incentive policies such as equity incentives for state-controlled listed companies, incentives for shares and dividends in state-owned technology-based enterprises, and employee shareholdings in mixed state-owned enterprises, without restrictions on pilot quotas."

\subsection{According to the Characteristics of Various State-owned Enterprises to Formulate and Issue Targeted Policy Documents}

There are many ways and means of mid- and longterm incentives, but the enterprise conditions, incentive crowds, and incentive effects applicable to various means are different. According to the definition at the 2018 National State-owned Enterprise Reform Symposium, medium- and long-term incentives for state-owned enterprises mainly include employee shareholding, equity incentives for listed companies, and equity dividend incentives for technology companies. In 2006, the State-owned Assets Supervision and Administration Commission issued the "Provisional Measures for the Implementation of Equity Incentives for State-owned Listed Companies (Domestic / Overseas)", in which special regulations were made for state-controlled listed companies on the basis of the original policy. In 2016, the "Interim Measures for Incentives for Equity and Dividends of State-owned Technology Enterprises" and "Opinions on Pilots for Employee Stock Ownership by State-owned Mixed-Owned Enterprises" were issued successively.[3] The state-owned technology-based enterprises' equity and dividend incentives were fully liberalized, and the employee shareholding of the stateowned mixed-ownership enterprises entered the standard pilot stage. So far, the medium- and long-term incentive policies for state-owned enterprises have comprehensively covered state-owned listed companies, state-owned technology-based enterprises, and stateowned mixed-owned enterprises. The legal environment for medium- and long-term incentive policies for stateowned enterprises is improving day by day, and the policy conditions for further promotion and implementation are in place.

The promulgation of relevant documents has created a good policy environment and atmosphere for the stateowned power enterprises to promote the medium and long-term incentive mechanism. It also provides a normative basis and requirements for related companies to implement mid- and long-term incentives. Stateowned power companies have a good foundation for further advancing the mid-to-long-term incentive mechanism in the vertical and horizontal directions.

\section{STATE-OWNED ENTERPRISES' MID-} AND LONG-TERM INCENTIVE POLICIES ARE IMPROVING

\subsection{The Number of Mid- and Long-term Incentive Companies has Increased Year by Year}

In terms of equity incentives for state-controlled listed companies, as of May 2019, a total of 92 listed companies controlled by 45 central enterprises have 
implemented equity incentive plans, accounting for $22.8 \%$ of domestic and foreign listed companies controlled by central enterprises, mainly distributed in communications and information Technology, scientific research and design, medicine, machinery, military industry, energy and other industries. In terms of equity and dividend incentives for state-owned technology companies, as of the end of 2018, 104 incentive programs for 24 technology-owned subsidiaries of central enterprises have entered the implementation stage, of which 74 programs were added in 2018, an increase of $247 \%$. Regarding the shareholding of employees in the pilot state-owned mixed-ownership enterprises, in accordance with the principle of "mature one household, promote one household", a total of 181 enterprises were selected for the pilot. The 10 pilot sub-enterprises at the state-owned enterprise level have all completed capital contributions, and the pilot enterprises at the local level have also completed the first batch of capital contributions. The follow-up choice is actively carrying out war investment negotiations, asset evaluation, entry transactions and other work.

\subsection{The Implementation of Mid- and Long- term Incentive Mechanisms for State-owned Enterprises has Achieved Good Results}

The implementation of the mid- and long-term incentive plan has provided great support and help to related companies in terms of promoting business performance improvement, stabilizing the core talent team, and stimulating employee innovation. As of May 2018, the average annual growth rate of the operating income, total profit, and market value of enterprises with equity incentives of more than one year implemented by state-controlled listed companies reached $16.7 \%, 14.6 \%$, and $7.0 \%$, respectively, which were significantly higher than the overall level.[4] The 30 state-owned technology enterprises that have completed the first batch of incentives have achieved a total profit and net profit increase of $41.6 \%$ and $45.6 \%$, respectively. Among the pilot projects of employee shareholding in state-owned mixed ownership enterprises, the total profits of 10 central pilot enterprises increased by $26 \%$ in 2018 . Companies that have already launched mid- and longterm incentives have achieved very impressive results. For example, in the past year of the implementation of equity incentives by Aerospace Science and Technology and Engineering Equipment Co., Ltd., not only has the company's revenue increased by $21.7 \%$ year-on-year in 2018 , but the company's attractiveness to professional talents has also greatly increased. Another example is that China Electric Power Research Institute Co., Ltd. has greatly stimulated the innovation enthusiasm of researchers through the implementation of job dividends since 2016. In 2018, the company completed 68 achievements transformation; since 2018, 541 patent authorizations have been obtained, and the company's benefits have also continued to grow; the average dividend of the A share listed company China Construction Group Co., Ltd. has implemented equity incentives for the past 5 years, reaching 6 billion yuan Compared with the first three years after listing, it has increased by more than 4 billion yuan.

The exploration and practice of various state-owned enterprises in the medium and long-term incentives not only help their own enterprises develop and progress, but also provide a lot of reference templates for other enterprises. In the follow-up implementation process, relevant companies can learn from successful experience and avoid detours, which is conducive to the smooth landing and promotion of mid- and long-term incentive mechanisms.

\section{UNDER THE NEW REFORM SITUATION, THE COMPANY'S MID- AND LONG-TERM INCENTIVE NEEDS ARE BECOMING STRONGER}

Since the 18th National Congress of the Communist Party of China, the reform of state-owned assets and state-owned enterprises and the reform of the electric power system have advanced in depth. State-owned power enterprises are facing double reform pressures, and the contradictions and problems they face are more complicated. Focusing on promoting the reform of the human resources management system and mechanism, stimulating the vitality of key core talents, and giving new momentum to the company's workforce has become the key to achieving the "ice-breaking" of reforms.

\subsection{The Reform Goals of State-owned Assets and State-owned Enterprises Require Further Strengthening of Positive Incentives to Improve the Overall Quality of the Workforce}

The 19th National Congress of the Communist Party of China stood at a new historical starting point and made major arrangements for the reform and development of state-owned enterprises. It is clearly proposed to cultivate world-class enterprises with global competitiveness, and to form a group of leading enterprises that lead the technological development of the global industry. Stateowned power enterprises shoulder a heavy responsibility. The company should enter the leading ranks in terms of innovation drive. The drive for innovation is essentially talent-driven, so we must focus on improving innovation mechanisms and stimulating vitality as key factors. To be able to enter the forefront of high-quality development. Pay attention to the quality and efficiency of enterprise development, so we must continuously improve the efficiency of talent use, and fully tap the potential kinetic energy of employees through effective incentives. To be able to practice the new development concept can enter the forefront. Adhere to the new development concept to 
guide the company's human resources work, so we must continue to expand the human resources work ideas, and share the company's development results with employees.

\subsection{Power System Reform Requires Reasonable Use of Mid- and Long-term Incentives to Maintain Sustainable Development}

Along with the successive issuance of the "No. 9 Document" and supporting documents in 2015, the new round of power system reform officially kicked off. The state-owned power enterprise's human resources working face accelerated the challenge of improving efficiency and maintaining team stability.

On the one hand, the cost pressure caused by the reform of transmission and distribution prices requires the company to further improve labor efficiency. This requires real and close connection between the company's development and the progress of employees through the implementation of mid- and long-term incentives, so that the two parties can be bundled into a community of interests. So as to effectively stimulate the internal motivation of employees, and achieve the purpose of improving work efficiency and reducing labor costs.[5]

On the other hand, the new regulatory model of "letting the two ends down and controlling the middle" has attracted a large number of electricity sales companies to enter the energy sector. This not only caused the company to face increased market competition and put forward higher requirements for improving talent efficiency. These emerging companies also dig a large number of mature talents from the company's existing workforce, including key core talents, which makes the company's talent loss phenomenon. Intensified, the stability of the workforce was hit. This requires the company to use mid- and long-term incentives so that the target of incentives must obtain profits by fulfilling the mid- and long-term goals of the company's development, unable to obtain incentive results in the short term, and effectively maintain the stability of the company's key core talent team.

\section{CONCLUSION}

The Party Central Committee and the State Council have provided huge support to state-owned enterprises in developing medium- and long-term incentives, while also regulating and restricting the implementation of medium- and long-term incentives for ongoing enterprises by issuing policy documents. Therefore, when carrying out medium- and long-term incentives, state-owned enterprises should first consider the direction and constraints of policy encouragement, follow the direction and objectives of policy support, and carry out work within the scope allowed by the policy.

In addition, the successful experience of a large number of state-owned enterprises also provides effective support for the further promotion and application of mid- and long-term incentive mechanisms. In the process of designing mid- and long-term incentive plans for state-owned power companies, they can learn from the success stories of similar companies and avoid related risks in advance.

\section{ACKNOWLEDGMENT}

This project is supported by the State Grid Corporation of China Technology Project "Research on Talent Supply and Demand Analysis Model and Supply Strategy Research Adapting to Company Strategy" (SGSC0000KXJS2000095).

\section{REFERENCES}

[1] Li, Y., Research on Establishing Mid- and Longterm Incentive Mechanism for State-owned Enterprises, in: Modern Commerce, vol.22, Beijing, China, 2017, pp. 129-130. DOI: 10.14097/j.cnki.5392/2017.22.048

[2] Jin, Z., Research on Mid- and Long-term Incentive Methods of Conventional Enterprises, in: Modern Economic Information, vol.12, Beijing, China, 2017, PP.70. DOI: 10.3969/j.issn.1001-828X.2017.18.050

[3] Deng, L., Discussion on Mid- and Long-term Incentives for Enterprises, in: Human Resources Management, vol.10, Beijing, China, 2013, pp.173. DOI: 10.3969/j.issn.1673-8209.2013.10.092

[4] Han. G., On the Reform of Mixed Ownership of State-owned Enterprises and the Design of Mid- and Long-term Incentive Mechanism, in: Hebei Enterprise, vol.1, 2020, pp. 20-21. DOI: 10.3969/j.issn.1008-1968.2020.01.006

[5] Wang, X., Research on Salary Incentive System in Human Resources Management of State-owned Enterprises, in: Accounting Study, vol.1, 2020, pp. 216-217. DOI: 10.3969/j.issn.16734734.2020.01.132 